\title{
T-Lymphocyte Subpopulations and Function during Murine Cytomegalovirus Infection
}

\author{
MATTHEW S. SELL, JAMES F. BALE, JR., AND ROGER H. GILLER \\ Divisions of Neonatology, Pediatric Neurology and Hematology-Oncology, Department of Pediatrics, University \\ of Iowa College of Medicine, Iowa City, Iowa 52242
}

\begin{abstract}
To study the effects of cytomegalovirus infection on T-lymphocyte subpopulations, we determined helper (Lyt 1.2) and suppressor (Lyt 2.2) T-lymphocyte subset numbers using monoclonal antibodies and measured lymphocyte responsiveness to mitogen during sublethal murine cytomegalovirus (MCMV) infection of 3-wk-old $\mathrm{Balb} / \mathrm{c}$ mice. MCMV-infected mice had reduced Lyt 1.2 to Lyt 2.2 T-lymphocyte ratios on days $1,3,5$, and 9 of infection. Alterations in T-lymphocyte subsets were accompanied by diminished lymphocyte response to concanavalin A. Lymphocyte responsiveness and Lyt 1.2 to Lyt 2.2 ratios were maximally reduced on day 5 of MCMV infection and correlated strongly with peak virus recovery from spleen, bone marrow, and peripheral blood leukocytes. These results indicate that acute MCMV infection of mice causes abnormalities in T-lymphocyte subset ratios and responsiveness to mitogen similar to the abnormalities observed in human cytomegalovirus infections. MCMV infection of mice is a useful model to study the mechanism by which cytomegalovirus infections induce altered T-lymphocyte subpopulations. (Pediatr Res 19: 583-587, 1985)
\end{abstract}

Abbreviations

Con A, concanavalin A

CMV, cytomegalovirus

MEM, minimum essential media

MCMV murine cytomegalovirus

pfu, plaque forming unit

Lyt 1.2, helper lymphocyte

Lyt 2.2, suppressor lymphocyte

Observations in humans and experimental animals indicate that infection with CMV adversely affects several parameters of host defense, including B-cell, T-cell, macrophage, and neutrophil functions (1-7). In humans an increased frequency of bacterial or fungal infections occurs in transplant recipients with primary CMV infections $(8,9)$. Renal transplant patients infected with CMV have reduced helper to suppressor T-cell ratios temporally related to the onset of the viral infection $(10,11)$ and have been at an increased risk for opportunistic infection when the T-lymphocyte subset was abnormal. Similarly, patients with $\mathrm{CMV}$ mononucleosis have altered ratios of T-helper to T-sup-

Received October 1, 1984; accepted February 13, 1985.

Address correspondence and reprint requests to Dr. James F. Bale, Jr., Department of Pediatrics, University of lowa Hospitals and Clinics, Iowa City, IA 52242.

Supported in part by Biomedical Research Support Grant RR 05372, Division of Research Facilities and Resources, National Institutes of Health. J.F.B. was supported by a Teacher-Investigator Development Award 7 K07 NS00805, from the National Institute of Neurological and Communicative Disorders and Stroke. pressor lymphocytes (12). These alterations in T-lymphocyte subset have been accompanied by diminished lymphocyte responses to mitogen stimulation. Such observations indicate that acute CMV infection alters the function and subset ratio of Tlymphocytes and that altered helper to suppressor ratios among transplant patients may be a marker for an increased rate of secondary infections.

In mice, MCMV infection suppressed the proliferation response of T-lymphocytes to the mitogens phytohemagglutinin and Con $\mathrm{A}$ as well as B-lymphocyte proliferation response to bacterial lipopolysaccharide $(4,6,13)$. In addition, neutrophil migration and chemotaxis have been decreased during the acute phase of MCMV infection (1). As a result of altered host defense mechanisms, MCMV-infected mice demonstrated enhanced mortality when challenged with a secondary bacterial or fungal agent $(2,3)$. Previous studies in mice have not investigated Tcell subpopulations during MCMV infection.

To study the effects of CMV infection on T-lymphocyte ratio, we infected 3-wk-old Balb/c mice with the Smith strain of MCMV and measured T-lymphocyte subsets using monoclonal antibodies. Our objectives included: 1) to determine Lyt 1.2. to Lyt 2.2 number and ratio during acute MCMV infection, 2) to measure lymphocyte proliferation response to Con $A, 3)$ to correlate changes in helper to suppressor ratio and lymphocyte function with recovery of infectious virus from blood, spleen, and bone marrow, and 4) to correlate these results with our previous observations regarding the timing of enhanced susceptibility of MCMV-infected mice to secondary infections.

\section{MATERIALS AND METHODS}

Animals. Three-week-old female Balb/c mice (Harlan-Sprague-Dawley, Madison, WI) were maintained in a controlled environment ( $12 \mathrm{~h}$ light-dark cycle, food and water ad libitum) during these experiments. Infected and control mice were housed separately.

Virus. The Smith strain of MCMV, obtained from Dr. Earl R. Kern, University of Utah, Salt Lake City, UT was used to prepare virus pools. As described previously (2), MCMV was prepared from MCMV-infected mice as a $10 \%(\mathrm{w} / \mathrm{v})$ homogenate of salivary gland tissue in Eagles' MEM containing $10 \%$ fetal calf serum, penicillin $(100 \mathrm{U} / \mathrm{ml})$, and streptomycin $(50 \mathrm{~g} / \mathrm{ml})$. The MCMV pools contained $1 \times 10^{7} \mathrm{pfu}$ of $\mathrm{MCMV} / \mathrm{ml}$ when titrated on mouse embryo fibroblast cell monolayers. For controls, a normal salivary gland pool was prepared in a similar manner using salivary glands from uninfected 3-wk-old mice.

Animal inoculation. In preliminary experiments, mice were inoculated with serial dilutions of the MCMV pool. A 0 to $20 \%$ mortality consistently occurred at an inoculum of $2 \times 10^{4} \mathrm{pfu}$ of $\mathrm{MCMV} /$ mouse. This inoculum infected all animals as indicated by ruffled fur, diminished activity, and subsequent positive cultures. All deaths occurred on days 7 or 8 of MCMV infection. 
In experiments measuring $T$-cell subsets and lymphocyte responsiveness, animals received a $0.1-\mathrm{ml}$ inoculum containing $2 \times 10^{4}$ pfu of MCMV intraperitoneal. Control animals received $0.1 \mathrm{ml}$ of a normal salivary gland preparation intraperitoneal.

Leukocyte preparation. On days $0,1,3,5,9,16$, and 30 after inoculation, groups of eight MCMV-infected and control animals were sacrificed for study. These days were chosen to correlate with previous experiments from this laboratory which studied combined MCMV and bacterial infections (2). Using microcollection pipettes (Unopette, Becton-Dickinson and Co., Rutherford, NJ) and smears of peripheral blood stained with Hemacolor (Harleco, Gibbstown, NJ), total and differential leukocyte counts were determined. Blood for lymphocyte assays was obtained via cardiac puncture and collected in heparinized $(10 \mathrm{U} / \mathrm{ml})$ syringes. The mononuclear cell fraction was separated on Ficoll-Hypaque gradients (14) and washed twice with RPMI-1640 with 5\% fetal calf serum (GIBCO, Grand Island, NY). The cells were resuspended to a final concentration of $1.0 \times 10^{6}$ cells $/ \mathrm{ml}$. Leukocyte viability was $\geqq 98 \%$ as judged by exclusion of trypan blue.

T-lymphocyte subset determination. Pure monoclonal antibodies directed against Lyt 1.2 and Lyt 2.2 surface antigens of Balb/ c mouse lymphocytes (New England Nuclear, Boston, MA) were used to determine the helper (Lyt 1.2) and suppressor (Lyt 2.2) lymphocyte subsets $(15,16)$. A 0.10 -ml aliquot of the mononuclear leukocyte fraction was incubated at $4^{\circ} \mathrm{C}$ for $30 \mathrm{~min}$ with $2.5 \mu \mathrm{l}$ of either Lyt-1.2 or Lyt-2.2 monoclonal antibody. The cells were then washed twice with RPMI-1640. To the cell pellet, $15 \mu \mathrm{l}$ of alkaline-phosphatase conjugated goat antimouse immunoglobulin (Cappel Laboratories, Cochranville, PA) were added, and the cells were allowed to incubate for $30 \mathrm{~min}$. The cells were again washed twice prior to adding $0.25 \mathrm{ml}$ of $\mathrm{SIg}$ indicator (Sigma Chemical Co., St. Louis, MO). Following a 30min incubation at $37^{\circ} \mathrm{C}$ the cells were resuspended in $1.0 \mathrm{ml}$ RPMI-1640, $0.05 \mathrm{ml} 0.12 \%$ hydrogen peroxide, and $0.025 \mathrm{ml}$ peroxidase indicator (Sigma Chemical Co.). The cells were centrifuged at $400 \times g$ for 5 min, resuspended in RPMI-1640, and counted using a standard light microscope. Using this technique, monocytes stained black, positive lymphocytes stained red, and negative lymphocytes did not stain. Control samples included cell suspensions incubated with goat antimouse alkaline-phosphatase conjugated immunoglobulin but without monoclonal antibody in order to rule out nonspecific binding of the goatantimouse $\operatorname{IgG}$ to the mouse lymphocytes.

Mitogen-induced proliferation assay. On various days after inoculation with either MCMV or normal salivary gland, mice were sacrificed and peripheral blood from groups of either three infected or three uninfected mice was pooled. Mononuclear leukocytes were isolated on Ficoll-Hypaque gradients, washed, and diluted to a concentration of $1 \times 10^{6}$ viable cells $/ \mathrm{ml}$ in RPMI-1640 with $10 \%$ fetal calf serum. Aliquots $(0.1 \mathrm{ml})$ of the leukocyte suspensions containing $1 \times 10^{5}$ cells $/ \mathrm{ml}$ were placed into flat-bottom plastic microwells ( 96 well microtiter plates, Corning, Corning, NY). On days 3 and 5 after MCMV infection, when the mice were leukopenic, groups of six infected or six uninfected mice were pooled to increase cell yield.

Con A, obtained as a lyophilized powder (Sigma Chemical Co.) was dissolved in RMPI 1640 and filter sterilized before use in these experiments. The cells were cultured in triplicate without Con A and with final dilutions of $2.0,3.0,4.0 \mu \mathrm{g} / \mathrm{ml}$ of Con A in a volume of $0.2 \mathrm{ml} /$ well (10). These concentrations of Con A were shown in preliminary experiments to induce maximal stimulation of murine lymphocytes. Cultures were incubated at $37^{\circ} \mathrm{C}$ in a humidified atmosphere of $5 \% \mathrm{CO}_{2}$ in air for $72 \mathrm{~h}$. Eighteen hours before harvesting, $1 \mu \mathrm{Ci}$ of methyl- ${ }^{3} \mathrm{H}$-thymidine (specific activity $6.7 \mathrm{Ci} / \mathrm{mmol}$; New England Nuclear) in a volume of $0.02 \mathrm{ml}$ was added to each well. The cell samples were harvested using a multiple sample harvester (Microharvester, Bellco Glass, Vineland, NJ) on fiber glass filters (Whatman, Clifton, $\mathrm{NJ}$ ), washed with distilled water, air-dried, and immersed in $3.0 \mathrm{ml}$ of Omnifluor toluene scintillation fluid (New England
Nuclear). Samples were then counted in a Beckman LS-100 liquid scintillation counter (Beckman, St. Louis, MO).

Virus assays. On days 1, 3, 5, 9, 16, and 30 of MCMV infection, samples of spleen, blood, and bone marrow were assayed in duplicate for MCMV on confluent monolayers of secondary mouse embryo fibroblast cells in 24-well tissue culture plates (Linbro, Flow Laboratories, McLean, VA) (4). Spleens were prepared as a $10 \% \mathrm{w} / \mathrm{v}$ homogenate in MEM, and peripheral mononuclear cells were obtained by Ficoll-Hypaque separation. For bone marrow cultures, the right femur was removed under sterile conditions and the marrow flushed out with $0.1 \mathrm{ml}$ of MEM. Samples were allowed to adsorb for $1 \mathrm{~h}$ and then overlaid with MEM containing 5\% fetal calf serum, $100 \mathrm{U} / \mathrm{ml}$ penicillin, $50 \mathrm{~g} / \mathrm{ml}$ streptomycin, and $0.5 \%$ agarose (SeaKem, Biomedical Systems, Springfield, NY). Culture data were expressed as log pfu of MCMV per gram of tissue, per $10^{6}$ mononuclear cells, or per milliliter of bone marrow aspirate.

\section{RESULTS}

Recovery of MCMV from spleen, blood, and bone marrow. MCMV was recovered from spleen homogenates on days 1 through 16 after inoculation. All MCMV infected mice had MCMV in homogenates of spleen on days 3 and 5 (Table 1). Peak titers of $1.6 \times 10^{6}$ pfu were observed on day 3 . Virus was recovered from the mononuclear leukocyte fraction of peripheral blood and from bone marrow aspirates on days 3 through 9 . On day 5 virus was recovered from the leukocytes from every MCMV-infected mouse. Titers of MCMV in the leukocyte fraction were similar to previous results studying Swiss-Webster mice (1). After day 9 only one animal had infectious MCMV present in the mononuclear leukocyte fraction.

Characterization of T-lymphocyte subsets. Table 2 summarizes

Table 1. Recovery of MCMV from spleen, peripheral blood mononuclear cells, and bone marrow (mean $\pm S D)^{*}$

\begin{tabular}{cccc}
\hline & $\begin{array}{c}\text { Spleen } \\
\text { Day after infection } \\
(\log \text { pfu/g) }\end{array}$ & $\begin{array}{c}\text { Mononuclear cells } \\
\left(\log \text { pfu/1 } / 10^{6} \text { cells }\right)\end{array}$ & $\begin{array}{c}\text { Bone } \\
\text { marrow }\end{array}$ \\
\hline 1 & $0.75 \pm 1.3$ & 0 & 0 \\
3 & $6.2 \pm 0.53$ & $1.1 \pm 0.89$ & $0.83 \pm 0.62$ \\
5 & $6.1 \pm 0.36$ & $2.4 \pm 0.40$ & $1.8 \pm 0.12$ \\
9 & $2.1 \pm 2.2$ & $0.55 \pm 0.95$ & $0.92 \pm 0.81$ \\
16 & $2.0 \pm 2.6$ & $0.30 \pm 0.79$ & 0 \\
30 & 0 & 0 & 0 \\
\hline
\end{tabular}

* Viral assays for infectious MCMV from various tissues document peak titers on day 5 after MCMV infection.

Table 2. Relationship of Lyt 1.2 to Lyt 2.2 T-cell ratio and responsiveness to Con $A(\text { mean } \pm S D)^{*}$

\begin{tabular}{|c|c|c|c|}
\hline \multirow[b]{2}{*}{ Day } & \multicolumn{2}{|c|}{ Lyt 1.2:Lyt 2.2} & \multirow{2}{*}{$\begin{array}{c}\% \text { reduction in Con A } \\
\text { response }\end{array}$} \\
\hline & Control & MCMV-infected & \\
\hline 0 & $2.0 \pm 1.3$ & & \\
\hline 1 & $2.3 \pm 1.2$ & $0.9 \pm 0.5 \dagger$ & 0 \\
\hline 3 & $1.9 \pm 0.6$ & $0.8 \pm 0.2 \dagger$ & 70 \\
\hline 5 & $2.7 \pm 1.4$ & $0.6 \pm 0.3 \dagger$ & 93 \\
\hline 9 & $1.5 \pm 0.5$ & $0.7 \pm 0.3 \dagger$ & 75 \\
\hline 16 & $1.8 \pm 0.8$ & $1.2 \pm 1.2$ & 62 \\
\hline 30 & $1.2 \pm 0.3$ & $1.1 \pm 0.7$ & 0 \\
\hline
\end{tabular}

* T-cell subset ratio in uninfected and MCMV-infected mice and relationship to Con A stimulation. The number of circulating lymphocytes reacting with monoclonal antibodies identifying T-cell subset surface antigens was determined during specified days of MCMV infection. The T-cell subset ratio in MCMV-infected mice is significantly depressed during the acute infection. Corresponding with the depressed T-cell subset ratio, a reduction in responsiveness to Con A stimulation occurs.

$\dagger p<0.01$ Wilcoxon rank sum test. 


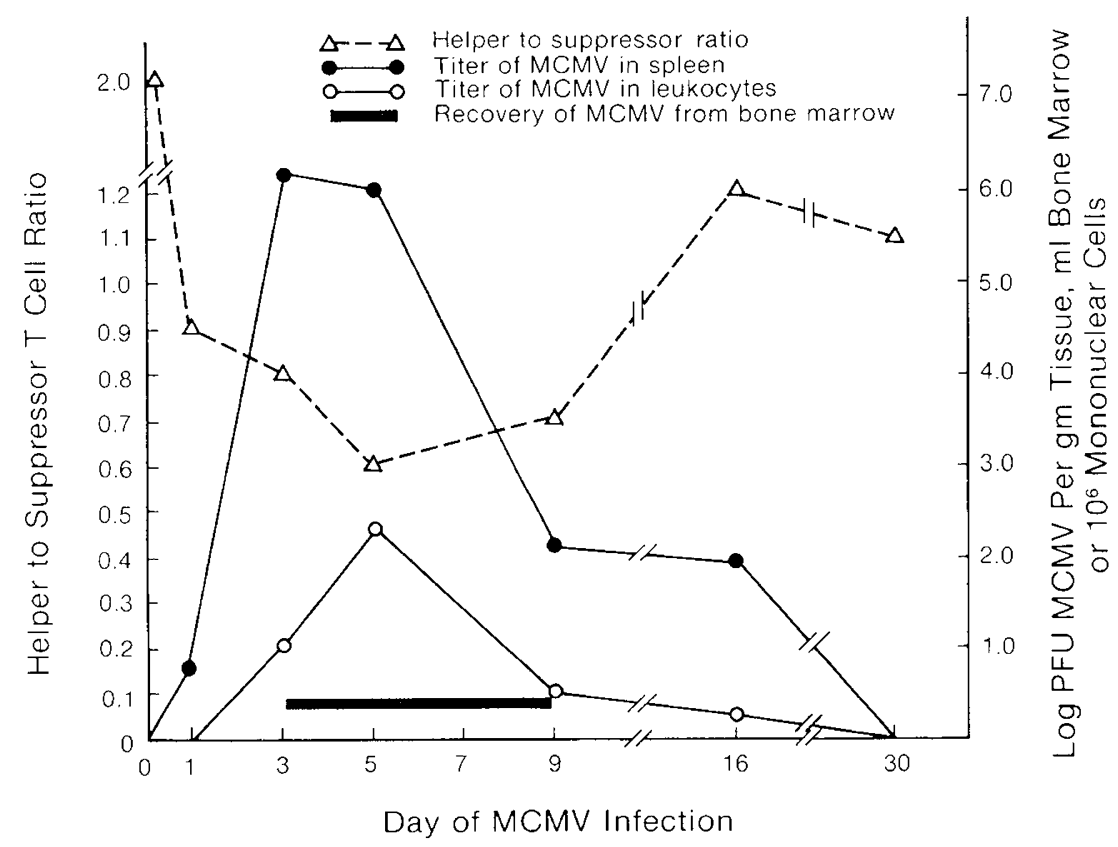

Fig. 1. Correlation of T-cell subset ratio to recovery of infectious MCMV from spleen, peripheral blood mononuclear leukocytes, and bone marrow. The depression in the $T$-cell subset ratio correlated with recovery of infectious virus from bone marrow $(r=-0.95, p<0.02)$ and peripheral blood mononuclear leukocytes $(r=-0.82, p<0.05)$ on days 3 to 30 of infection.

Table 3. Total lymphocyte count and absolute Lyt 1.2 to Lyt 2.2 T-cell number (mean \pm SD)*

\begin{tabular}{|c|c|c|c|c|c|c|}
\hline \multirow[b]{2}{*}{ Day } & \multicolumn{2}{|c|}{ Total lymphocytes } & \multicolumn{2}{|c|}{ Lyt 1.2 number } & \multicolumn{2}{|c|}{ Lyt 2.2 number } \\
\hline & Control & MCMV & Control & MCMV & Control & MCMV \\
\hline 0 & $1147 \pm 550$ & & $458 \pm 235$ & & $249 \pm 130$ & \\
\hline 1 & $1113 \pm 1056$ & $1500 \pm 1576$ & $403 \pm 361$ & $353 \pm 248$ & $197 \pm 147$ & $514 \pm 414$ \\
\hline 3 & $1090 \pm 653$ & $441 \pm 211 \dagger$ & $478 \pm 290$ & $136 \pm 72 \pm$ & $286 \pm 235$ & $164 \pm 68$ \\
\hline 5 & $1024 \pm 431$ & $725 \pm 339$ & $351 \pm 165$ & $159 \pm 88 \dagger$ & $143 \pm 145$ & $292 \pm 128$ \\
\hline 9 & $1694 \pm 1197$ & $3033 \pm 1251$ & $675 \pm 646$ & $740 \pm 630$ & $455 \pm 389$ & $1012 \pm 530 \dagger$ \\
\hline 16 & $2558 \pm 790$ & $1734 \pm 1543$ & $560 \pm 370$ & $249 \pm 126$ & $381 \pm 246$ & $302 \pm 172$ \\
\hline 30 & $1549 \pm 878$ & $3079 \pm 2759$ & $628 \pm 282$ & $1226 \pm 1451$ & $530 \pm 235$ & $1069 \pm 679$ \\
\hline
\end{tabular}

* Monoclonal antibody labeled lymphocyte subsets were counted. Decreased helper cell number on days 3 and 5 of infection in MCMV-infected animals accounted for the depressed T-cell subset ratio. However, an increase in suppressor cells on day 9 of infection produced the lowered $\mathrm{T}$-cell subset ratio.

$\dagger p<0.05 t$ test (MCMV infected versus control on same day).

$\ddagger p<0.02 t$ test (MCMV infected versus control on same day).

the ratio of Lyt 1.2 to Lyt 2.2 ratios on days 1 through 9 after infection. Beginning the first day after infection with MCMV, the Lyt 1.2 to Lyt 2.2 ratio fell to less than 1.0 with the control values remaining greater than 1.9 . On day 5 , the ratio reaches its lowest value of 0.6 , the same day that infectious virus was uniformly recovered from the spleen homogenates, mononuclear leukocytes, and bone marrow aspirates of all infected animals. Decreases in the Lyt 1.2 to Lyt 2.2 cell ratio appeared to correlate closely with recovery of infectious virus from tissues (Fig. 1). Correlation coefficients between lymphocyte subset ratio and virus recovery were $r=-0.82$ for peripheral blood and $r=-0.95$ for bone marrow.

The lowered T-lymphocyte subset ratios on days 3 and 5 reflected a significant reduction in the absolute number of Lyt 1.2 lymphocytes. On day 9 an increase in the Lyt 2.2 cell subpopulation accounted for the inverted Lyt 1.2 to Lyt 2.2 cell ratio (Table 3 ). The peripheral white blood cell count showed a significant leukopenia in MCMV-infected mice on day 3 (white blood cells of $863 \pm 371 / \mathrm{mm}^{3}$ in MCMV infected versus 2530 $\pm 1019 / \mathrm{mm}^{3}$ in controls, $p<0.01$ ), followed by a significant leukocytosis on day 9 (white blood cells of $6324 \pm 2775 / \mathrm{mm}^{3}$ in MCMV-infected animals versus $2425 \pm 1509 / \mathrm{mm}^{3}$ in controls, $p<0.01, t$ test). During the first week of infection the MCMVinfected mice also demonstrated a significant lymphopenia, while during the second week of infection, lymphocytosis occurred (Table 3). The latter change corresponded to an increase in the absolute number of suppressor $T$ cells.

Mitogen response of mononuclear leukocytes. Mononuclear leukocyte response to the mitogen Con A was used to measure lymphocyte function and permit correlation with changes in Tcell subset ratio. Data from 9 to 21 mice per day were pooled, and the response of mononuclear cells from MCMV-infected mice was compared to the response of cells from uninfected animals. Mononuclear leukocytes from MCMV-infected mice were significantly less responsive to Con A stimulation on days $3,5,9$, and 16 after infection than were cells from control animals (Fig. 2).

The reduction in the mononuclear cell response to mitogen correlated with recovery of infectious virus from peripheral blood and with the reduction in the Lyt 1.2 to Lyt 2.2 ratio (Table 2). The greatest reduction in mitogen response occurred on day 5 , the same day that the Lyt 1.2 to Lyt 2.2 ratio was maximally reduced. By day 30 of MCMV infection, mitogen responsiveness, as well as the Lyt 1.2 to Lyt 2.2 ratio, had returned to normal. 


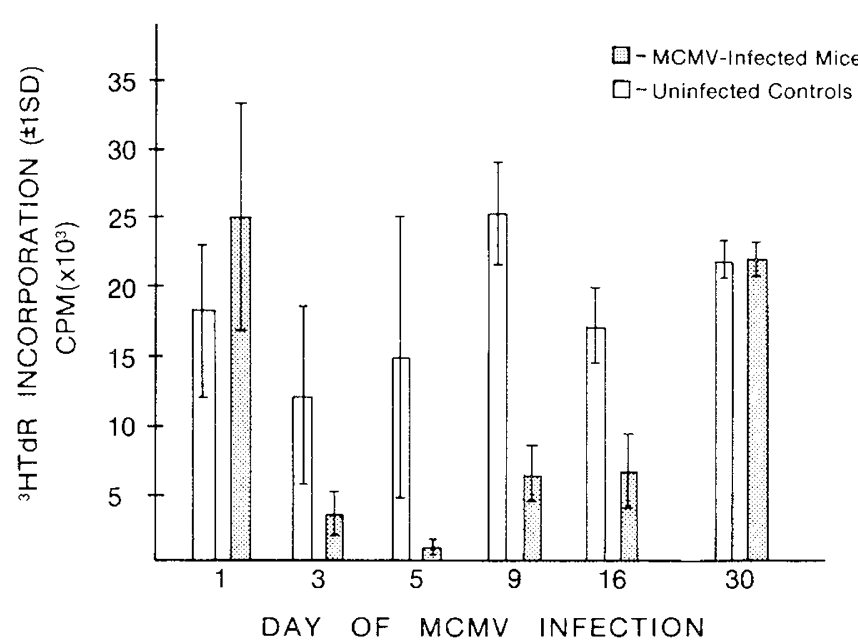

Fig. 2. Con A response of mononuclear leukocytes from uninfected and MCMV-infected mice at various days of infection. At each day $1 \times$ $10^{5}$ mononuclear cells were incubated with Con $\mathrm{A}$ for $72 \mathrm{~h}$. To evaluate mitogen responsiveness, $1 \mu \mathrm{Ci}$ of tritiated-thymidine $\left({ }^{3} \mathrm{HTdR}\right)$ was added to each microtiter well $18 \mathrm{~h}$ before harvest. ${ }^{3} \mathrm{HTdR}$ incorporation is determined by subtracting the mean cpm of untreated cells from the mean $\mathrm{cpm}$ of Con $\mathrm{A}$ treated cells of triplicate samples $(\triangle \mathrm{cpm})$.

\section{DISCUSSION}

In the current experiments, acute MCMV infection of 3-wkold Balb/c mice resulted in a decreased Lyt 1.2 to Lyt 2.2 lymphocyte ratio and diminished responsiveness of peripheral blood lymphocytes to the mitogen Con A. Lyt 1.2 to Lyt 2.2 ratio was reduced 1 day after infection and remained low through day 9. Lymphocyte responsiveness to Con A became abnormal on day 3 of MCMV infection, and this abnormality persisted through day 16 . Thus, changes in lymphocyte subset ratio preceded alterations in lymphocyte function. Lyt 1.2 to Lyt 2.2 lymphocyte ratio and lymphocyte responsiveness to mitogens were both maximally reduced on day 5 . These abnormalities correlated strongly with recovery of virus from the spleen, peripheral blood, and bone marrow of MCMV-infected animals.

Kelsey et al. (4) previously observed maximally suppressed responses of splenic lymphocytes to the mitogens phytohemagglutinin and lipopolysaccharide on days 4 and 5 after MCMV infection with a return to normal by the 15 th day. Alloreactivity, measured by the mixed lymphocyte response was suppressed during the first 10 days after infection and also became normal by day 15 (13). Similarly, Osborn et al. (7) observed impaired antibody response to an injected antigen on days 3 through 14 after MCMV infection. Thus, immunosuppression by MCMV affects both B-cell and T-cell functions during the first 2 wk of infection.

Suppressed cell-mediated immunity in humans with CMV mononucleosis has been shown by decreased lymphocyte responsiveness to mitogens $(5,17)$. Carney et al. (12) also demonstrated that the helper to suppressor T-cell ratio was decreased during acute CMV mononucleosis and that the abnormal ratio correlated with decreased lymphocyte responsiveness. During convalescence, the T-lymphocyte subset ratio showed a progressive return toward normal and the mitogen-stimulation response also normalized. In additional experiments in humans, Rinaldo et al. (18) observed enhanced mitogen stimulation following in vitro removal of the suppressor T-cells which had been induced during CMV mononucleosis. This suggested that the depressed immune function correlated with the emergence of increased suppressor $\mathrm{T}$-cells and that a normal response to mitogen could be restored when the excess suppressor cells were removed in vitro. Reduced lymphocyte responsiveness and altered helper to suppressor ratio may contribute to the prolonged illness characteristic of some CMV infections.
In the young infant with symptomatic congenital CMV infection, the abnormalities in lymphocyte subpopulations have been less striking. Pass et al. (19) observed modestly increased suppressor T-lymphocyte numbers and reduced helper to suppressor ratios in infants less than $1 \mathrm{yr}$ of age. These abnormalities were transient and did not correlate with chronic viral excretion or persistently reduced lymphocyte blastogenic responsiveness to CMV antigens. In contrast, Shannon et al. (20) reported persistent mitogen hyporesponsiveness and abnormal T-lymphocyte subpopulations in a young infant with transfusion acquired CMV infection.

Our observations regarding altered helper to suppressor lymphocyte subset ratio during MCMV infection of mice relate most closely to abnormalities which have been noted during CMV infections of human organ and bone marrow transplant recipients $(10,21,22)$. Schooley et al. $(11,21)$ observed that abnormal T-lymphocyte subset ratios accompanied CMV infections of renal transplant recipients and identified patients at risk for opportunistic infections with bacterial or fungal pathogens. Inversion of the helper to suppressor T-lymphocyte ratio in this prospective study correlated with the onset of clinically apparent $\mathrm{CMV}$ infection, and often preceded the onset of opportunistic infections. In bone marrow transplant patients, Schroff et al. (22) observed a strong correlation between declining helper to suppressor T-lymphocyte ratio and CMV infection and Verdonck and DeGast (23) observed similar abnormalities during both latent and primary CMV infections. Although the mechanism by which CMV infection affected the helper to suppressor lymphocyte ratio was not known, Schroff et al. (22) speculated that abnormal helper to suppressor ratios in these patients recovering from bone marrow transplantation were attributable to bone marrow suppression induced by CMV infection.

In the murine model, we observed abnormal helper to suppressor lymphocyte subset ratios on days $1,3,5$, and 9 of MCMV infection. Previous experiments from this laboratory (2) and those of Hamilton et al. (3) demonstrated that MCMV-infected mice had enhanced susceptibility to secondary infection with bacterial or fungal agents when mice were challenged with the agents on days 1 through 4 of MCMV infection. Moreover, all deaths during combined MCMV and bacterial infection with either Escherichia coli or Pseudomonas aeruginosa were observed during days 1 through 10 of MCMV infection. These observations thus suggest that altered Lyt 1.2 to Lyt 2.2 ratios correlate strongly with susceptibility of MCMV-infected mice to secondary infections.

In summary, these experiments demonstrated that acute MCMV infection of mice was associated with inversion of the helper to suppressor T-lymphocyte subset ratio. Inversion of this ratio correlated with reduced lymphocyte responsiveness to Con A and with recovery of MCMV from blood and bone marrow. Although the mechanism for these changes in helper to suppressor ratio is not known, these studies indicate that abnormal helper to suppressor T-lymphocyte ratio was an accurate marker of acute MCMV infection, particularly the viremic phase. Moreover, these animal studies corroborate the observations in humans which suggest that inverted T-lymphocyte subset ratios correlate with an increased risk for opportunistic infections in $\mathrm{CMV}$-infected organ transplant recipients. MCMV infection of mice may be a useful model to elucidate the mechanism by which CMV infections induce altered T-lymphocyte subpopulations.

\section{REFERENCES}

1. Bale JF Jr, Kern ER Overall JC Jr Baringer JR 1983 Impaired migratory and chemotactic activity of neutrophils during murine cytomegalovirus infection. J Infect Dis 148:518-525

2. Bale JF Jr, Kern ER, Overall JC Jr, Glasgow LA 1982 Enhanced susceptibility of mice infected with murine cytomegalovirus to intranasal challenge with Escherichia coli: pathogenesis and altered inflammatory response. J Infect Dis 145:525-531

3. Hamilton JR, Overall JC, Glasgow LA 1976 Synergistic effect on mortality in 
mice with murine cytomegalovirus and Pseudomonas aeruginosa, Staphylococcus aureus, or Candida albicans infections. Infect Immun 14:982-989

4. Kelsey DK, Olsen GA, Overall JC Jr, Glasgow LA 1977 Alteration of host defense mechanisms by MCMV. Infect Immun 18:754-760

5. Rinaldo CR Jr, Carney WP, Richter BS, Black PH, Hirsch MS 1980 Mechanisms of immunosuppression in cytomegalovirus mononucleosis. J Infect Dis 141:488-495

6. Selgrade MJ, Ahmed A, Sell KW, Gershwin ME, Steinberg AD 1976 Effect of $\mathrm{MCMV}$ on the in vitro responses of $\mathrm{T}$ and $\mathrm{B}$ cells to mitogens. $\mathrm{J}$ Immun 116:1459-1465

7. Osborn JE, Blazkovec AA, Walker DL 1968 Immunosuppression during acute murine cytomegalovirus infection. J Immunol 100:835-844

8. Chatterjee SN, Fiala M, Weiner J, Stewart JA, Stacey B, Warner N 1978 Primary cytomegalovirus and opportunistic infections: incidence in renal transplant recipients. JAMA 240:2446-2449

9. Rand KH, Pollard RB, Merigan TC 1978 Increased pulmonary superinfections in cardiac-transplant patients undergoing primary cytomegalovirus infection. N Engl J Med 298:951-953

10. Fische M, Soulillou JP, Bignon JD, Billavdel S, Guenel J 1984 T-lymphocyte monitoring in kidney transplant recipients undergoing cytomegalovirus infection or rejection episodes. Transplantation 37:421-423

11. Schooley RT, Hirsch MS, Colvin RB, Cosimi AB, Tolkoff-Rubin NE, McCluskey RT, Burton RC, Russell PS, Herrin JT, Delmonico FL, Giorgi JV, Henle W, Rubin RH 1983 Association of herpes virus infections with Tlymphocyte-subset alterations, glomerulopathy, and opportunistic infections after renal transplantation. N Engl J Med 308:307-313

12. Carney WP, Rubin RH, Hoffman RA, Hansen WP, Healey K, Hirsch MS 1978 Analysis of T-lymphocyte subsets in cytomegalovirus mononucleosis. J Immunol 126:2114-2116

13. Kelsey DK, Overall JC Jr, Glasgow LA 1978 Correlation of the suppression of mitogen responsiveness and the mixed lymphocyte reaction with the proliferative response to viral antigen of splenic lymphocytes from cytomegalovirus-infected mice. J Immunol 121:464-469

14. Boyum A 1974 Separation of blood leucocytes, granulocytes and lymphocytes. Tissue Antigens 4:269-274

15. Goldsmith JC, Moseley PL, Monick M, Brady M, Hunnighake GW 1983 Tlymphocyte subpopulation abnormalities in apparently healthy patients with hemophilia. Ann Intern Med 98:294-296

16. Cantor H, Shen FW, Boyse EA 1976 Separation of helper T cells from suppressor $T$ cells expressing different Ly components. J Exp Med 143:1391 1401

17. Carney WP, Hirsch MS 1981 Mechanisms of immunosuppression in cytomegalovirus mononucleosis. II. Virus-monocyte interactions. J Infect Dis 144:47-54

18. Rinaldo CR Jr, Ho M, Hamoudi WH, Gui X, DeBiasio RL 1983 Lymphocyte subsets and natural killer cell responses during cytomegalovirus mononucleosis. Infect Immun 40:472-477

19. Pass RF, Roper MA, August AM 1983 T-lymphocyte subpopulations in congenital cytomegalovirus infection. Infect Immun 41:1380-1382

20. Shannon K, Ball E, Wasserman RL, Murphy FK, Luby J, Buchanan GR 1983 Transfusion-associated cytomegalovirus infection and acquired immune deficiency syndrome in an infant. J Pediatr 103:859-863

21. Schooley RT, Hirsch MS, Colvin RB, Cosimi AB, Russell PS, Delmonico FL, Giorgi JV, Rubin RH 1983 Letter to the editor. N Engl J Med 309:111

22. Schroff RW, Gale RP, Fahey JL 1982 Regeneration of $T$ cell subpopulations after bone marrow transplantation: cytomegalovirus infection and lymphoid subset imbalance. J Immunol 129:1926-1930

23. Verdonck LF, DeGast GC 1984 Is cytomegalovirus infection a major cause of $\mathrm{T}$ cell alterations after (autologous) bone marrow transplantation? Lancet 1:932-935

\title{
Mode of Inhibitory Action of Bilirubin on Protein Kinase C
}

\author{
KIMIHIKO SANO, HAJIME NAKAMURA, AND TAMOTSU MATSUO \\ Department of Pediatrics, Kobe University School of Medicine, Kobe, Japan
}

\begin{abstract}
Ca}^{2+}$-activated, phospholipid-dependent protein kinase (protein kinase $C$ ) is widely distributed in mammalian tissues. Accumulating evidence has revealed that protein kinase $\mathrm{C}$ as well as cAMP-dependent protein kinase plays important roles in various cellular functions. The purpose of this study is to examine the effect of bilirubin on protein kinase $C$ and $\mathrm{CAMP}$-dependent protein kinase activity in a cell-free system as a cause of bilirubin toxicity to the central nervous system. Bilirubin inhibited protein kinase $C$ activity in a dose-dependent manner. This effect was markedly diminished by the addition of human serum albumin at a molar ratio of bilirubin to albumin of less than 1.0. Kinetic analysis revealed that bilirubin did not compete with phospholipid, diacylglycerol, or calcium. Bilirubin also inhibited cAMP-dependent protein kinase, but did not compete with cAMP. The inhibitory effect of bilirubin on protein kinase $C$ seems to be irreversible because removal of bilirubin by Sephadex G-25 column chromatography did not restore the protein kinase $C$ activ-
\end{abstract}

Received May 8, 1984; accepted February 13, 1985.

Correspondence to Dr. Kimihiko Sano, Department of Medicine, National Jewish Hospital and Research Center/National Asthma Center, 3800 East Colfax Avenue, Denver, CO 80206 ity. Observations reported herein suggest that bilirubin, especially in its free form, induces an irreversible change to the catalytically active site of protein kinase C. (Pediatr Res 19: 587-590, 1985)

\section{Abbreviation}

Protein kinase $\mathrm{C}$, calcium-activated, phospholipid-dependent protein kinase

Bilirubin is toxic to the central nervous system, causing encephalopathy, especially in low birth weight premature infants with hyperbilirubinemia and acidosis. The toxic mechanism of bilirubin has been extensively investigated. Several enzymes relating to oxidative phosphorylation and to metabolisms of carbohydrate, amino acid, and lipid are affected by bilirubin (for a review see Reference 1). However, no specific enzyme has been singled out as a target of bilirubin toxicity.

Recent evidence has revealed that protein phosphorylation is a very important pathway in various cellular functions including those of the nervous system (for a review see Reference 2). To 